\title{
RAHASIA MERAIH SUKSES DUNIA AKHIRAT PERSPEKTIF TEMATIK SURAH AL KAUTHAR
}

\author{
Ahmad Masykur \\ Sekolah Tinggi Ilmu Ushuluddin (STIU) \\ Al-Mujtama' Pamekasan \\ E-mail : www.abizlēemail.com
}

\begin{abstract}
Abstrak:
Al-Qur'an merupakan sumber segala ilmu. Banyak sekali ilmu yang berkaitan dengan al-Qur'an. Hal itu karena para pengkaji alQur'an bermaksud merealisasikan banyak tujuan dan memandang al-Qur'an dari segi yang berbeda. Kajian terhadap al-Qur'an sesungguhya dapat dilakukan dengan melihat berbagai objek, mulai dari aspek sejarah kodifikasinya, qiraahnya, asbab nuzulnya sampai pada perkembangan penafsirannya. Dan Kajian terhadap sisi penafsiran nampaknya justru yang sangat mengalami perkembangan cukup signifikan. Jika kita dapat mencermati, dari suatu generasi kepada generasi berikutnya penafsiran al-Qur'an memiliki corak dan karakteristik yang berbeda-beda. Hal ini disebabkan oleh banyak faktor, antara lain adalah adanya perbedaan situasi sosio-historis di mana seorang mufassir hidup. Bahkan situasi politik yang terjadi ketika mufassir melakukan kajian dan penafsiran terhadap al-Qur'an juga ikut mewarnai penafsi-rannya. Di samping itu cakupan makna yang terkandung dalam al-Qur'an memang sangat luas, begitu pula perbedaan dan corak penafsiran juga disebabkan perbedaan keahlian yang dimiliki oleh masing-masing mufassir. Al-Qur'an memang merupakan kitab yang mengandung kemungkinan banyak penafsiran. Sehingga adanya pluralitas penafsiran al-Qur'an adalah sah-sah saja, sepanjang dapat dipertanggungjawabkan secara moral dan ilmiah. Bahkan Penafsiran dapat diibaratkan sebuah "organisme" yang selalu tumbuh dan berkembang. Ia akan selalu mengalami perubahan dan perkembangan seiring dan senafas dengan kemajuan tantangan yang dihadapi manusia sepanjang masa.
\end{abstract}

Kata Kunci : Al-Qur'an, perkembangan penafsiran, penuntun sukses

Absract:

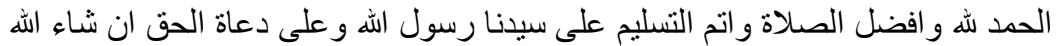
وبعد فسيجد القارئ الكريم على هذه الورقات باختصار ها مايعين على البقاء في الدنيا 
بالذكر الجميل وفي الآخرة مع الثو اب الجزيل ـ وذلك أن هذه السورة كا المقابلة للسورة

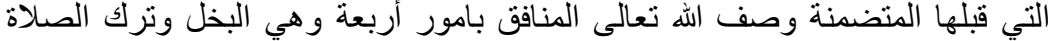

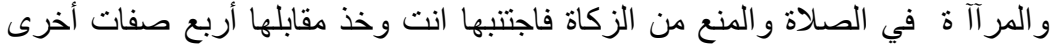

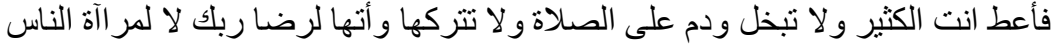

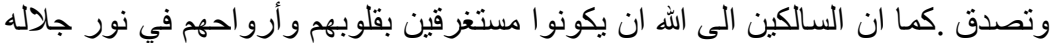

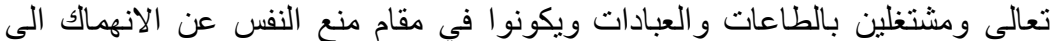
اللذات و الثهو ات العاجلة فأعطيتم "الكوثرات

Keywords: القران، تطور التفسير، هداية للناس

\section{Prolog}

Kajian terhadap al-Qur'an sesungguhya dapat dilakukan dengan melihat berbagai objek, mulai dari aspek sejarah kodifikasinya, qiraahnya, asbab nuzulnya sampai pada perkembangan penafsirannya. Dan Kajian terhadap sisi penafsiran nampaknya justru yang sangat mengalami perkembangan cukup signifikan. Munculnya berbagai kitab tafsir yang sarat dengan berbagai ragam metode maupun pendekatan, merupakan bukti bahwa upaya untuk menafsirkan al-Qur'an memang tidak pernah berhenti. Hal ini merupakan keniscayaan sejarah, karena di satu sisi umat Islam pada umumnya ingin selalu menjadikan al-Qur'an sebagai mitra dialog dalam menjalani kehidupan dan mengembangkan peradaban. Proses dialektika antara teks yang terbatas, jelas dan mutawatir serta konteks yang tidak terbatas itulah sebenarnya yang menjadi pemicu dan pemacu bagi perkembangan tafsir.

Jika kita dapat mencermati, dari suatu generasi kepada generasi berikutnya penafsiran al-Qur'an memiliki corak dan karakteristik yang berbeda-beda. Hal ini disebabkan oleh banyak faktor, antara lain adalah adanya perbedaan situasi sosio-historis di mana seorang mufassir hidup. Bahkan situasi politik yang terjadi ketika mufassir melakukan kajian dan penafsiran terhadap al-Qur'an juga ikut mewarnai penafsirannya.

Di samping itu memang cakupan makna yang terkandung dalam alQur'an memang sangat luas, begitu pula perbedaan dan corak penafsiran juga disebabkan perbedaan keahlian yang dimiliki oleh masing-masing mufassir. Al-Qur'an memang merupakan kitab yang mengandung kemungkinan banyak penafsiran. Sehingga adanya pluralitas penafsiran al-Qur'an adalah sah-sah saja, sepanjang dapat dipertanggungjawabkan secara moral dan ilmiah. Bahkan Penafsiran dapat diibaratkan sebuah "organisme" yang selalu tumbuh dan berkembang. Ia akan selalu mengalami perubahan dan perkembangan seiring dan senafas dengan kemajuan tantangan yang dihadapi manusia. 
Rahasia meraih sukses dunia akhirat

Perspektif tematik surah al kauthar

Al-Qur'an merupakan sumber ilmu. Banyak sekali ilmu yang berkaitan dengan Al-Qur'an. Hal itu karena para pengkaji Al-Qur'an bermaksud merealisasikan banyak tujuan dan memandang al-Qur'an dari segi yang berbeda.

Ketika Rasulullah masih hidup, para sahabat menanyakan semua persoalan mereka kepada beliau, atau melihat sikap dan perilaku beliau. Setelah rasulullah wafat tidak ada orang yang mempunyai otoritas kenabian untuk menjelaskan berbagai masalah yang selalu datang, dan para sahabat selalu berupaya menyampaikan dan mengedepankan al-Qur'an untuk menjawab. ${ }^{1}$

Sehingga di masa sahabat, banyak dipelajari hal yng terkait dengan alQur' an untuk mengetahui penafsiran sebuah ayat demi mendekati penafsiran Rasulullah. karena itu mereka "haus" untuk mengetahui sebab-sebab turunnya sebuah ayat, sebagai alat bantu dalam memahami dan menafsirkan ayat tersebut secara berurutan yang kemudian beerkembang menjadi penafsiran per-surah atau per-tema.

\section{Pembahasan}

Penafsiran terhadap surah-surah tertentu dari al-Qur'an telah banyak ditulis oleh para Ulama mulai dari surah yang terpanjang sampai pada surah yang pendek-pendek, di bawah ini akan dibahas mengenai penafsiran salah satu surah al-Qur'an yang pendek yaitu surah al-Kauthar.

A. Tek Ayat surah al-Kauthar dan Terjemahanya

Pembahasan mengenai satu surah secara menyeluruh dan utuh, dengan menjelaskan arti umum dan khususnya, menguraikan munāsabah atau korelasi antar-berbagai tema yang dikandungnya, sehingga menjadi jelas bahwa surat itu merupakan satu kesatuan yang kokoh dan ia seakan-akan 
merupakan satu rantai emas yang setiap gelang-gelang darinya bersambung satu dengan lainnya, sebagaimana pembahasan surah al-Kauthar berikut ini.

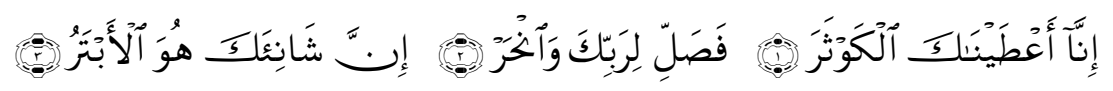

"Sesungguhnya Kami telah memberikan kepadamu Al Kauthar. Maka shalatlah kamu, dan berkurbanlah. Sesungguhnya pembenci-mu itulah yang akan binasa" (QS. Al-Kauthar: 1-3).

B. Waktu diturunkan dan Korelasi dengan surah sebelumnya

Terdapat perbedaan di antara para Ulama mengenai tempat dan waktu turunya surah al-Kauthar :

1. Surah al-Kauthar adalah termasuk salah satu surah Makkiyah ${ }^{2}$, terdiri dari tiga ayat, berada setelah surah al-Mā'ūn dalam urutan surah al-Qur'an.

Adapun hubungan surah ini dengan surah sebelumnya (surah alMà'ūn), adalah, ketika Allah telah menjelaskan dalam surah sebelumnya tentang orang yang mendustakan agama dengan empat macam sifat, yaitu al-bukhl (bakhil), tidak mau melakukan shalat, riya, dan tidak mau memberikan pertolongan, maka dalam surah Al Kauthar ini Allah menyebutkan sifat-sifat yang dikaruniakan kepada Rasulullah Saw. berupa kebaikan dan keberkahan. Disebutkan bahwa beliau diberi Al-Kauthar, yang berarti kebaikan yang banyak, dorongan untuk melakukan shalat dan membiasakan-nya, ikhlas dalam melakukannya dan bersedekah kepada kaum fakir miskin. ${ }^{3}$

2. Anas bin Malik mengatakan bahwa kami berada di sekeliling Rasul, tiba-tiba Beliau terlena sebentar kemudian Beliau mengangkat kepala dan bersabda yang artinya: 'Diturunkan kepadaku tadi satu surah'. Lalu Beliau membaca surah alKauthar dan bersabda, "Tahukah kalian apa al-Kautsar? Kami menjawab, "Allah dan RasulNya yang mengetahui". Lalu Beliau 
Rahasia meraih sukses dunia akhirat

Perspektif tematik surah al kauthar

melanjutkan, 'Ia adalah sungai yang dijanjikan Tuhan kepadaku. Di sana terdapat banyak kebajikan. Ia adalah telaga yang banyak didatangi (untuk diminum) ummatku pada hari kiamat ${ }^{4}$

Berdasar hadits ini banyak juga para ulama yang mengatakan bahwa surah al-Kauthar diturunkan di Madinah, karena Anas bin Malik baru masuk Islam pada masa awal hijrah nabi Muhammad saw ke Madinah. ${ }^{5}$

3. Latar belakang sejarah diturunkanya

Surah ini murni untuk Rasulullah sebagaimana dikatakan Sayyid Qutb dalam Tafsirnya yang menggambarkan kehidupan Dakwah dan juru dakwah terutama pada tahap awal. ${ }^{6}$ Terdapat beragam riwayat yang menceritakan tentang latar belakang sejarah diturunkanya surah ini, salah satu diantaranya yang diriwayatkan oleh Ibnu Abì Hātim. Ketika putra Rasulullah saw (AlQāsim) meninggal, al-'Aṣ bin Wāil berkata bahwa Muhammad telah terputus keturunannya, maka turunlah surah al-Kautsar (Sesungguhnya orang-orang yang membenci kamu dialah orang yang terputus). Riwayat yang senada dikatakan bahwa 'Uqbah bin Abì Mua'it berkata,'Tidak seorang anak laki-lakipun yang hidup bagi nabi saw, sehingga keturunannya terputus'. Maka Surah al-Kauthar turun sebagai bantahan terhadap ucapan tersebut. ${ }^{7}$

Ada riwayat lain menyebutkan bahwa Surah ini diturunkan berkaitan dengan orang-orang musyrik Makkah dan orang-orang munafik Madinah mereka mencela dan mengejek Nabi Saw. dengan beberapa hal. Pertama, orang-orang yang mengikuti beliau adalah orang-orang $d u^{\prime}$ 'afá', sementara orang-orang yang tidak mengikutinya adalah para pembesar dan pejabat. Andaikan agama yang dibawakan itu benar, tentu pembela-pembelanya itu ada dari kelompok orang pandai yang memiliki kedudukan di antara rekanrekannya. ${ }^{8}$

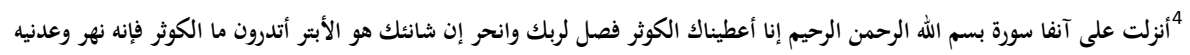


Pernyataan seperti itu bukanlah hal baru yang hanya terjadi pada Nabi Muhammad, kaum para Nabi terdahulu juga berkata hal serupa kepada nabi mereka. Seperti dikisahkan dalam al-Qur'an: "Maka berkatalah pemimpinpemimpin yang kafir dari kaumnya: Kami tidak melihat kamu melainkan (sebagai) manusia biasa seperti kami, dan kami tidak melihat orang-orang yang mengikuti kamu melainkan orang-orang yang hina-dina di antara kami yang lekas percaya saja, dan kami tidak melihat kamu memiliki sesuatu kelebihan apa pun atas kami, bahkan kami yakin bahwa kamu adalah orangorang yang dusta." (QS. Hūd [11] :27).

Atas dasar latar belakang itu, surah al-Kauthar turun untuk menegaskan kepada Rasul Saw. bahwa apa yang diharapkan oleh orangorang kafir itu merupakan harapan yang tidak ada kebenarannya; untuk menggoncangkan jiwa orang-orang yang tidak mau menyerah dalam pendiriannya, orang-orang yang berkepala batu; untuk menolak tipuan orang-orang musyrik dengan sebenar-benarnya; dan untuk mengajarkan kepada mereka bahwa Rasul akan ditolong, dan pengikut-pengikutnya (yang dianggap lemah oleh merekapun) akan memperoleh kemenangan. ${ }^{9}$

Memang sudah begitu adanya, orang yang paling cepat memenuhi dakwah Rasul adalah para ç 'afá'. Itu disebabkan, di antaranya, karena mereka tidak memiliki harta sehingga tidak perlu takut hartanya akan tersiasiakan. Orang-orang ç $^{\prime}$ 'afắ juga tidak memiliki pangkat atau kedudukan yang menyebabkan mereka takut akan kehilangan pangkat atau kedudukannya.

Keberadaan dan kebersamaan para ç $^{\prime} a f^{\prime}{ }^{\prime}$ ' itu seringkali tidak disenangi oleh para pembesar. Karena itu seringkali terjadi perdebatan antara mereka dan para rasul. Mereka berusaha untuk melenyapkan dan mengganggu pengikut-pengikut Rasul (yang mereka anggap lemah), namun Allah menolong rasul-Nya, memperkuat dan memperkokoh pengikutnya.

Sikap para pembesar seperti itu terjadi pula pada Rasul Saw. Sungguh para pembesar telah menentang beliau karena kedengkian mereka kepada Rasul dan para pengikutnya yang ber-kedudukan rendah menurut mereka. Kemudian, ketika mereka melihat putra-putra Rasulullah meninggal, mereka pun berkata: "Terputuslah keturunan Muhammad, dan dia menjadi abtar." Mereka menganggap hal itu sebagai aib, sehingga mereka mencela beliau dan berusaha memalingkan orang lain dari mengikutinya. Apabila mereka

\footnotetext{
لها أهلها: نحن خير أم هذا الصنبور المنبتر من قومهونحن أهل الحجيج، وعندنا منحر البدن، قال : أنتم خير. فأنزل الله فيه هذه الآية، وأنزل

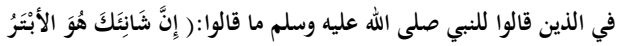

${ }^{9}$ Asbabun Nuzul surah al-Kautsar, Qomaruddin Shaleh, dkk
} 
melihat kesulitan yang turun dan menimpa orang-orang Mukmin, mereka senang dan menunggu kekuasaan itu bergeser kepada mereka.

4. Makna al-Kauthar

Al-Bukhārì dan Ahmad meriwayatkan bahwa pada suatu saat sekian banyak orang akan digiring nanti di surga dan akan diberi minum dari telaga yang bernama al-Kauthar. Yang diberi minum dari telaga hanyalah umat Rasulullah Saw. tetapi ketika sudah mendekat ke telaga al-Kauthar, mereka diusir oleh para malaikat. Lalu Rasulullah berteriak, "Sahabatku, sahabatku." Kemudian Allah berfirman, "Tidak. Mereka bukan sahabatmu. Engkau tidak mengetahui apa yang mereka perbuat sepeninggalmu." Rasulullah pun berkata, "Celakalah orang yang mengganti ajaran-ajaran agamaku setelah aku meninggal. ${ }^{10}$

Adapun makna dari al-Kauthar ulama menyebutkanya sangat banyak bahkan sampai diriwayatkan ada dua puluh enam pendapat tentang apa yang dimaksud dengan al-Kauthar, antara lain:

- Telaga di Surga

- Kebaikan yang banyak

- Keturunan Rasulullah Saw

- Sahabat-sahabat dan pengikut Rasul hingga hari kiamat.

- Ulama di kalangan umat Muhammad Saw

- Al-Quran dengan segala keutamaannya yang banyak

- Nubuwwah;

- Dimudahkannya al-Qur'an;

- Islam;

- Tauhid;

- Ilmu;

- Hikmah;

- Bekal atau belanja dalam jumlah yang banyak.

- Yang banyak memberi dan sebagainya. ${ }^{11}$

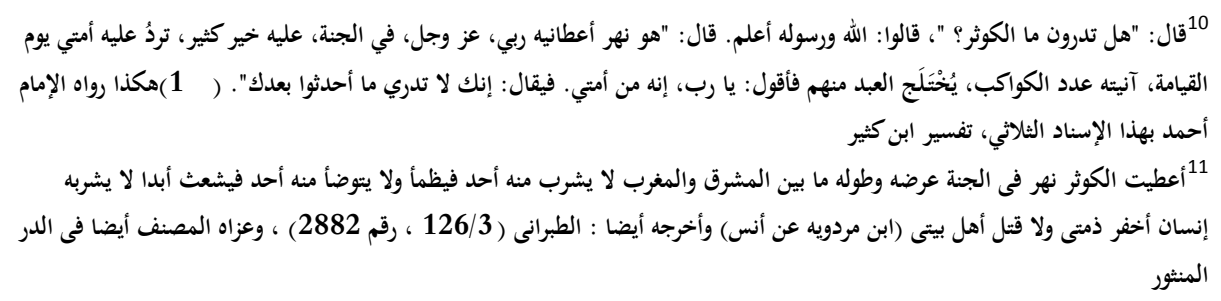


Di sini perlu kita mengambil tariqah al-jam 'i (teori penggabungan). Kita mengambil yang umum, al-Kauthar adalah kenikmatan yang banyak, yang dikaruniakan kepada Nabi Muhammad Saw. dan umatnya. Dan kenikmatan itu bisa berupa al-Qur'an, atau petunjuk Allah, atau bertambahnya pengikut beliau sampai akhir zaman hingga tidak terputus setelah beliau meninggal dunia, dan atau bisa juga telaga di surga. ${ }^{12}$ Sehingga termasuk orang-orang yang meraih sukses di dunia dan sukses pula di akhirat.

5. Pemahaman Ulama dan korelasi antara ayat-ayatnya

Islam lahir dalam konteks merespon budaya dan pandangan hidup dalam masyarakat Arab pada saat itu. Makkah saat itu mengalami kehancuran tatanan, struktur sosial, dan krisis kemanusiaan yang muncul dalam bentuk perbudakan, penguasaan kekayaan yang dimonopoli oleh segelintir orang. Hingga kemudian orang-orang yang lemah dan miskin semakin tidak berdaya. Dalam konteks demikianlah Islam lahir sebagai agama pembebas manusia dari perbudakan, kemiskinan, dan diskriminasi, baik ras, ekonomi dan hak hidup dan membela kaum tertindas.

Adanya keniscayaan fenomena lemah-kuat, kaya-miskin dan pintarbodoh saja tidak masalah selagi tidak ada kedzaliman, penganiayaan dan penindasan yang terjadi sebagai akibatnya. Dalam kenyataanya kita sering menyaksikan orang atau pihak lemah dianiaya oleh pihak kuat. Akibatnya yang lemah makin lemah, yang kuat makin kuat. Sebagai umat Islam tentu kita akan kembalikan semuanya ke ajaran Islam. Lalu bagaimana Al-Qur'an melihat ketertindasan.

Dengan surah ini Allah menegaskan bahwa telah memberikan kepada Nabi Muhammad pemberian yang banyak, telah mengaruniainya berbagai karunia, yang tidak mungkin sampai pada hakikatnya. Apabila musuhmusuhnya menganggap enteng dan kecil karunia itu, maka itu disebabkan karena kerusakan pikiran dan lemahnya persepsi mereka. Shalatlah karena Tuhanmu dan berkurbanlah! Begitu pula dari kalimat وانحر yang memiliki arti mengorbankan dan menyembelih hewan unta, dapat dipahami bahwa diperlukan mengorbankan sesuatu yang amat berharga karena fungsi serta kegunaan unta pada saat itu yang multi sehingga merupakan kepemilikan yang sangat berharga. Demikianlah jalan meraih sukses di dunia dan di akhirat kelak. Jadikanlah shalatmu hanya kepada Tuhan saja, dan

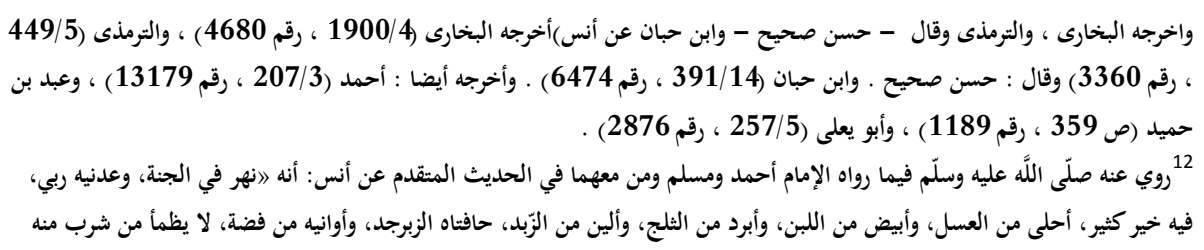


sembelihlah untamu pengorbananmu di jalan Allah juga. niscaya, Allah akan memeliharamu dan melimpah-kan kepadamu segala nikmat-Nya.

Makna surah ini dapat diketahui melalui ayat penutupnya. Allah telah ان شانئك هو menghalangi kebaikan dari orang-orang yang membenci RasulNya terhalangi untuk mengingat-Nya, hartanya dan keluarganya, sehingga pada gilirannya, di akhirat ia akan merugi akibat dari semua perbuatan yang tidak terpuji tersebut, mereka tidak membekali diri dengan amalan shalih saat hidup di dunia, sebagai bekal di hari akhiratnya. Hatinya akan terhalangi dari kebaikan, sehingga dia tidak mengenali kebaikan, apalagi mencintainya, hati mereka penuh dengan kedengkian, kebencian, kedzaliman dan memusuhi serta menindas orang-orang muslim terlebih kaum du'afä' yang pada ahirnya mendatangkan pertolongan Allah untuk membela kaum lemah tersebut.

Maka berhati-hatilah, jangan membenci sesuatu yang datang dari Rasulullah atau menolaknya untuk memuaskan hawa nafsu, atau disibukkan dengan syahwat atau urusan dunia. Sesungguhnya Allah tidak mewajibkan untuk taat kepada seseorang, kecuali taat kepada Rasul-Nya, dan mengambil apa yang datang darinya. Maka barang siapa yang taat atau ditaati, sesungguhnya hal itu terjadi hanya dengan mengikuti Rasul. Seandainya diperintahkan dengan sesuatu yang menyelisihi Rasul, maka tidak perlu ditaati.

Setelah menggembirakan Rasul Saw. dengan sebesar-besarnya kabar gembira, dan meminta beliau untuk bersyukur kepada-Nya atas nikmat dan kesempurnaannya, lalu Allah menegaskan bahwa musuh-musuh beliaulah yang justru akan terkalahkan dan terhinakan, ان شانئك هو الأبتر. Sesungguhnya pembencimu, baik yang dulu maupun yang sekarang, akan terputus namanya dari kebaikan dunia dan akhirat, sehingga keturunanmu akan kekal dan akan kekal juga nama dan jejak-jejak keutamaanmu sampai hari kiamat."

Sebenarnya para pembenci itu tidaklah membenci Rasul karena kepribadiannya. Mereka sebetulnya mencintai beliau lebih dari kecintaan kepada mereka sendiri. Namun, mereka marah kepada apa yang dibawa oleh beliau berupa petunjuk dan hikmah yang merendahkan agama mereka, mencela apa yang mereka sembah, dan menyeru mereka ke dalam sesuatu yang berbeda dengan apa yang mereka lakukan selama ini.

Allah sudah menegaskan dan membuktikan kepada pembencipembenci Rasul pada zaman beliau, mereka ditimpa kehinaan dan kerugian, dan tidak tersisa dari mereka kecuali nama yang buruk. Dia juga menegaskan dan membuktikan bahwa Nabi Saw. dan orang-orang yang 
Rahasia meraih sukses dunia akhirat

Perspektif tematik surah al kauthar

mendapat petunjuk akan mendapatkan kedudukan di atas apa pun, sehingga kalimah mereka menjadi kalimah yang paling tinggi. ${ }^{13}$

Karunia ini utuh dan berkesinambungan sebab kalimat pada ayat ini diawali dengan kata inna yang menunjukkan penegasan dan realisasi kandungan berita. Demikian juga, Allah menggunakan fi'il madi dalam kalimat ini, yang bertujuan sebagai penekanan kejadian peristiwa, sebab obyek yang sifatnya harapan yang berasal dari Dzat Yang Maha Mulia, terhitung sebagai hal yang pasti terjadi.

Selanjutnya, kata nahr, juga memiliki beberapa makna. Salah satu arti kata nahr adalah berkurban. Arti yang lain adalah bagian dada sebelah atas. Sebagian mufassir menjelaskan yang dimaksud dengan nahr ialah mengangkat tangan lurus dengan bahu sebelah atas. Sehingga maknanya adalah, "Shalatlah kepada Tuhanmu, ucapkan kebesaran nama Tuhanmu sambil mengangkat tangan selurus bahu."

Pendapat ini didasarkan kepada hadis yang diriwayatkan oleh Abí Hātim, al-Hakim, Ibnu Mardawaih, dan al-Baihaqi, dalam Sunannya, dari ATi bin Abi TTālib, ia berkata: "Ketika surah ini diturunkan Nabi bertanya kepada Jibril: 'Apa yang dimaksud dengan nahr yang diperintahkan oleh Allah di sini?' Jibril berkata: 'Yang dimaksud di sini bukan berkurban. Maksud kata ini adalah memerintahkanmu untuk mengangkat tangan saat menghormat dalam shalat, saat takbir, ruku, dan mengangkat kepala dari ruku. Sebab, itulah shalat kami dan shalat malaikat yang berada di langit yang tujuh. Segala sesuatu itu memiliki perhiasan-nya. Dan perhiasan shalat adalah mengangkat tangan pada setiap takbir. ${ }^{14}$

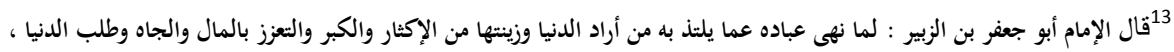

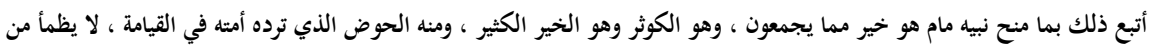

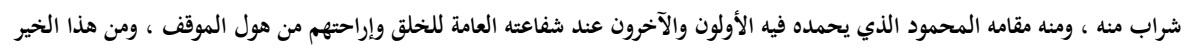

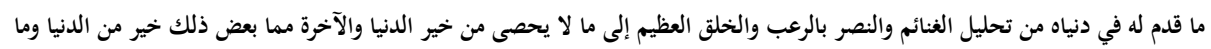

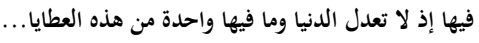

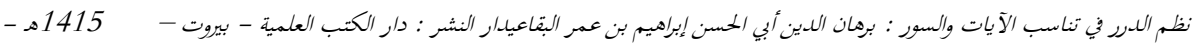
1995

14 عن على قال : لما نزلت إنا أعطيناك الكوثر . فصل لربك وانحر ق قال النبى - صلى الله عليه وسلم - لجبريل ما هذه النحيرة التى أمرنى

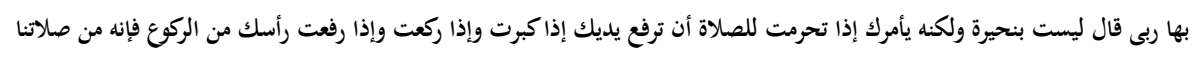

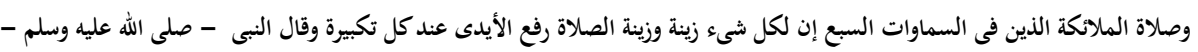

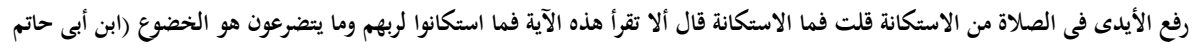

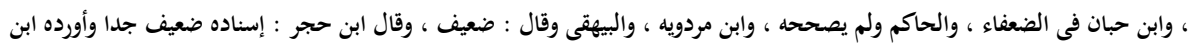

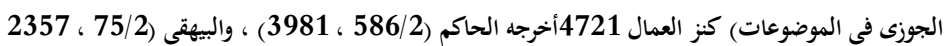


Begitu pula mengenai al-abtar, ulama Tafsir menyebutkan beberapa hal, yaitu: Dulu, pengikut-pengikut Rasul Saw. Yang pertama adalah kelompok du'afá', fuqarā' dan orang miskin. Kebanyakan mereka bodohbodoh sehingga diejek dengan sebutan sufahä, orang-orang bodoh, walaupun kemudian Allah menegaskan, alā innahum humu al-sufahā, mereka (para pembesar) itulah yang bodoh. Mereka (para pembesar) itu meng-anggap bahwa kalau agama yang dibawa oleh Muhammad itu benar, tentu pengikutnya adalah orang-orang pandai, orang-orang besar, dan orangorang yang mengerti. Tetapi, mengapa para pengikutnya justru orang-orang bodoh? Karena itulah mereka menganggap bahwa agama itu akan cepat abtar, dan akan cepat lenyap, cepat terputus.

Sebagaimana diriwayatkan bahwa Rasulullah Saw. Mempunyai beberapa orang putra. Putra tertua bernama al-Qāsim. Kemudian Zainab, Abdullāh, Ummu Kulthūm, Ruqayyah, dan Fātịmah. Al-Qāsim meninggal. Setelah ia meninggal, Abdullah pun meninggal. Maka, berkatalah al-'Ash bin Wāil al-Sahmī, salah seorang pembesar Quraisy: "Sudah terputus keturunan Muhammad; ia menjadiabtar, orang yang terput us keturunannya." Sebab itulah Allah menurunkan ayat, Inna shāni'aka huwa al-abtar (Sesunguhnya pembencimulah yang akan binasa). Itulah pula sebabnya sebagian ulama menjelaskan bahwa yang dimaksud alkauthar dalam surah ini adalah keturunan Rasulullah Saw., yakni janji Allah bahwa keturunan Muhammad tidak akan terputus, melainkan beranak-pinak dalam jumlah yang banyak. Dahulu, orang Arab menyebut seorang anak dengan nama bapaknya. Jadi, jika seseorang tidak mempunyai anak, maka namanya tidak akan disebut-sebut orang. Dan ternyata, nama Rasulullah dan para pengikutnya terus berlanjut dengan kenangan yang baik, hingga sekarang. ${ }^{15}$

Orang-orang musyrik disebut abtar antara lain karena tujuan mereka terputus sebelum mereka mencapainya. Menurut asal katanya, al-abtar adalah binatang yang terpotong ekornya. Adapun yang dimaksud al-abtar di sini ialah orang yang namanya tidak berlanjut dan jejaknya tidak kekal. Pengumpamaan kekalnya sebutan yang baik dan berlanjutnya jejak yang indah dengan ekor binatang karena ekor binatang itu mengikuti binatangnya dan menjadi perhiasan baginya. Sehingga, orang yang tidak memiliki sebutan yang kekal dan jejak indah yang berlanjut diibaratkan sebagai orang yang ekornya terlepas atau terputus. ${ }^{16}$

Demikianlah sunnatullah bahwa pengikut dakwah para Nabi pada umumnya berasal dari kelompok du'afá', dan bahwa para nabi dan

\footnotetext{
${ }^{15}$ Sayyid Quṭ, Fì Zilāl al-Qur'ān

${ }^{16}$ Sayyid Quṭb, Fỉ Zilāl al-Qur'ān tafsir surah al-Kauthar
} 
pengikutnya selalu memilih bergaul dengan kelompok $d u^{\prime} a f f^{-}$'. Bahkan di banyak tempat Islam berkembang pesat karena para ulama dan tokohnya mendekati kelompok orang yang lemah. Islam memiliki daya tarik yang besar bagi kelompok du' 'afá' dan orang-orang lemah. Hal ini kiranya perlu ditegaskan berkali-kali. Karena, selama ini orientasi dakwah kita hanya tertuju kepada kelompok elit saja, atau kelompok menengah yang sedang bangkit. Sementara orang-orang miskin, du $^{\prime}$ afá' didekati oleh agama lain, sehingga beberapa tempat telah banyak yang mengikuti ajakan mereka. Begitu pula yang dimaksud $d^{\prime} u^{\prime}$ 'afa' dalam al-Qur'an bukan saja lemah dalam arti materi, tapi juga ilmu sekalipun titik beratnya adalah $\underline{d} u^{\prime}$ 'afá' dari segi materi. Orang yang lemah dari sisi kekayaan, biasanya lemah juga dari sisi ilmu pengetahuan, kehidupan politik, dan kehidupan sosial.

\section{Epilog}

Al-Kauthar adalah pemberian Allah yang tiada terhitung, yang dikaruniakan kepada Muhammad Saw. Dan kenikmatan itu bisa berupa alQur'an, atau petunjuk Allah, atau bertambahnya pengikut beliau sampai akhir zaman hingga tidak terputus setelah beliau meninggal dunia, dan atau bisa juga telaga di surga, yang demikian itu merupakan rangkaian yang dapat menuntun seseorang meraih sukses di dunia dan di akhirat kelak.

Jadi walaupun al-Kauthar pada konteks surat al-Kauthar ditujukan kepada Rasulullah saw (karena menggunakan kata ganti $\mathrm{ka} / \mathrm{kamu}$ ), namun tidak berlebihan kiranya jika kita juga berharap untuk memperolehnya. Apalagi jika dikaitkan dengan makna al-kauthar yang dapat bermakna sangat luas sesuai dengan makna harfiyah. Semoga kita juga memperoleh alkauthar, dapat minum telaga di surga, mempunyai keturunan shalih dan shalihah, dan karunia Allah lainnya, tentu saja dengan ketekunan melaksanakan shalat serta ibadah yang lain dan dengan kerelaan berkorban di jalan Allah Subhānahū wa ta'àlā ( فصل لربك و انحر ).

Karena dari seluruh pilihan hidup manusia, intinya hanya dua: kebaikan dan kejahatan. Kedua pilihan itu telah ditiupkan secara inspiratif (ilham) dalam setiap jiwa manusia. Secara fitrah, setiap orang mampu membedakan kebaikan dari kejahatan, setidaknya secara universal, sebagaimana diisyaratkan al-Qur'an: "Kami telah menunjukkan kepada manusia dua jalan" (QS. [90]: 10); "Maka Allah mengilhamkan kepada jiwa manusia (jalan) kefasikan dan ketakwaannya" (QS. [91]: 8); "Sesungguhnya Kami telah menunjukinya jalan (yang lurus): ada yang bersyukur dan ada pula yang kafir" (QS. [76]: 3).

Sangatlah kurang tepat kalau ada orang menyatakan bahwa seorang penjahat tidak berpotensi menjadi baik, juga tidak benar bila ada yang 
mengatakan bahwa seorang alim tidak mempunyai bakat jadi orang jahat. Setiap orang berpotensi atau berbakat untuk menjadi satu di antara dua: baik, atau jahat, dzalim atau didzalimi dan Islam memerintahkan pemeluknya untuk selalu menolong orang yang dzalim dengan mencegah kedzalimanya dan membela orang yang didzalimi dan tertindas melalui jalur usaha dan berdoa dengan ikhlas serta kesiapan mengorbankan segalanya di jalan Allah dalam meraih sukses dan ridha-Nya di dunia dan di akhirat.

$$
\text { و العلم عند الله واليه المرجع و المأَب }
$$

\section{Daftar Pustaka}

Al-Bāqi', Fu'ād 'Abd. Al-Mu'jam al-Mufahraz li Alfāz al-Qur'ān al-Karìm, Maktabah Dahlan, t. th.

Buchori, Didin Saefuddin. Pedoman Memahami Kandungan al-Qur'an, Bogor: Granada Sarana Pustaka, 2005.

Al-Farmawi Abd Hay. Metode Tafsir Maudhu'i dan Cara Penerapannya, terj. Rosihon Anwar. Bandung: Pustaka Setia, 2002.

Al-GhazāTi, Muhammad. Kaifa Nata’āmal Ma’a al-Qur'ān, Kairo: Dār alMa'ārif, t.th.

Hamid, Shalahuddin. Study Ulumul Qur'an, Jakarta: Intimedia, 2002.

Al-Hashimi, 'Abd al-Hamid. Al-Rasūlu al-'Arabiyyu al- Murabbī, terj. Ibn Ibrahim dengan judul Mendidik Ala Rasulullah, Jakarta: Pustaka Azzam, 2001.

Hayat, Zakiyatul, Pemeliharaan Anak Yatim Dalam Persfektif Al-Qur'an, Skripsi, Banjarmasin: IAIN Antasari, 2002.

Hidayat, Rachmat Taufiq, Khazanah Istilah al-Qur'an, Bandung: Mizan, 1999.

Al-Husain. Ahmad bin Faris bin Zakariya Abū. Mu'jam Maqāyis al-Lughah. Beirūt: Dār al-Fikr, t.th, Jld. VI.

Al-Jurjānī, 'A đỉ ibn' Muhammad. Kitāb al-Ta'rifăt, Beirūt: Dār al-Kutub al'Ilmiyyah, 1408 H/ $1988 \mathrm{M}$.

Al-Marāghì, Ahmad Mushṭafá. Tafsìir al-Marāghī, ter. Bahran Abu Bakar dan Hery Noer Aly, cet. I, juz. I, II, IV, VIII, XII, Semarang: Toha Putra, 1986.

Al-Math, Muhammad Faiz. Min Mu'jizāt al-Islām, ter. Masykur Halim dengan judul Keistimewaan-keistimewaan Islam, Jakarta: Gema Insani Press, 1994.

Nashiruddin Baidan. Metodologi Penafsiran Al-Qur'an. Yogyakarta: Pustaka Pelajar, 2005. 
Salim, Abd. Muin. Metodologi Tafsir; Sebuah Rekonstruksi Epistemologis; Memantapkan Keberadaan Ilmu Tafsir Sebagai Disiplin Ilmu. (Orasi Pengukuhan Guru Besar di hadapan Rapat Senat Luar Biasa IAIN Alauddin Ujung Pandang, pada tanggal 28 April 1999.

Salim Basyarahil dan Muchotob Hamzah dengan judul Tafsir Fi Zhilal AlQur'an: Di bawah Naungan Al-Qur'an, jilid II dan IV, Jakarta: Gema Insani Press, 2000.

Shihab, Umar. Kontekstualitas al-Qur'an: Kajian Tematik atas Ayat-Ayat Hukum dalam al-Qur'an, Jakarta: Penamadani, 2003. 